\title{
FITRAH-BASED EDUCATION
}

\author{
Mardiah Astuti \\ A Lecturer of Faculty of Teacher Training and Education \\ UIN Raden fatah Palembang \\ Email :diahfajri@yahoo.co.id
}

Naskah diterima : 13 Februari 2017, direvisi : 22 Februari 2017, disetujui : 20 April 2017

\begin{abstract}
In the general concept of Islam, it is stated that primordial human nature (Fitrab in Arabic) is that human beings are born with an innate inclination of tawhid (Oneness). Existing creation and the natural structure has the fact that human beings are born with their natural belief of one God which is called tawhid religion. Islam, as a Fitrah religion, fits not only in men's diversity but also supports their growth and development. This makes their existence completed with perfect personality.

The concept of education on the basis of fitrah has two primary goals. Firstly, it is to trigger and encourage the development of good personality rooted from Fitrah of the students. The good personality has two main dimensions, which are social and personal dimension, which lead to self awareness. By having self awareness, students are expected to have fundamental potential which should be developed optimally. Secondly, it is to return back to th concept of Oneness so that the universe becomes a means of Zikr (devotional acts in Islam in which short phrases or prayers, glorifying Allah, are repeatedly recited silently within the mind or aloud) and learning sources for students.

In line with the goals of the Fitrah concept in the islamic educational system, students' Fitrah can be built correctly and perfectly as a moslem. A pious man who has great relationship with Allah SWT, other human beings, and nature positively and constructively is called Manusia yang beriman dan bertaqwa serta memiliki berbagai kemampuan aktualisasi hubungan dengan Allah swt, sesama manusia, dan alam secara positif konstruktif, inilah yang disebut transcedental humanism theocentric
\end{abstract}

Key Words : Education, Fitrah, Human Being

Pengutipan: Astuti, Mardiah. (2017). Fitrah-Based Education. JMIE: Journal of Madrasah Ibtidaiyah Education, 1(1), 2017, 81-95. sd.v1i1.26. 


\section{Background}

The substance of the teachings of Islam at its core is to uphold human values. At the level of its actualization, dignity and glory of human beings will be realized when they are able to draw closer to God, because they came from God and will return to God. Islam is a religion of nature that brings benefit to mankind.

Al-Quran, a major source of Islam, often talks about Fitrah, normatively laden with transcendental values of God and man. It means that on the one hand it focuses on Fitrah of human beings with their resources, both physical and spiritual aspects, which its quality is ready to be developed and improved through humanisering process which makes human's existence more meaningful. On the other hand, the development of quality of human resources is carried out in harmony with the principles of Oneness, both rububiyah and uluhiyah (Achmadi, 2005 : 11-12).

In the general concept of Islam, it is stated that primordial human nature (Fitrah in Arabic) is that human beings are born with an innate inclination of tawhid (Oneness). Creations exist and the natural structure has the fact that human beings are born with their natural belief of one God which is called tawbid religion. Islam, as a Fitrah religion, fits not only in men's diversity but also support their growth and development. This makes their existence completed with perfect personality.

\section{Definition of Fitrah}

Based on etymology, Fitrah is derived from the Arabic vocabulary fa-ra-tha, which means "incident", hence the word Fitrab comes from a verb meaning "to make" (Arifin, 2000 : 88). In another sense, the interpretation of Fitrab is derived from the word fathara, khalaqa and ansy'a which are used in the Qur'an which means "to create", to make something that did not previously exist and is still the archetype that needs improvement. Dictionary al Munjid explains that the literal meaning of Fitrah is al Ibtida'u wa al ikhtira'u, namely al shifat allati yattashifu Biha kullu maujudin fi awwali khalqihi Zamani. Another meaning is shifatu al human al thabi'iyah. Other than that, the meaning is al dinu wa al sunnah (Ma'luf, 2000 : 588).

Abu Ala al-Maududi says that human being is born on this earth by his mother as a Muslim (surrender) who has different obedience to God, but on the other hand, he is free to be Muslims or non-Muslims (Abdul A'la, 1966). Therefore, in relation to the aspect of the terminology of Fitrah, besides having a potential to become a man with Tawhid religion, he is also free to follow the rules of his surroundings to actualize the potential of Tawhid (submission to God) or not that, depending on how high the level of his surroundings gives positive or negative impacts to his Fitrah. Therefore, Al-Mawdudi's explanation about Fitrah simply shows that eventhough human beings are given an ability to think, freedom to act 
and choose, in fact he was born as Muslims, in the sense that all of his behaviors are likey to surrender to his God (Abdul A'la, 1966).

Regarding Fitrah, the Fuqoha has established rights of human Fitrah, as defined by them, which includes five things: 1) din (religion), 2) life, 3) intellect, 4) Pride, and 5). According to Armai, in a broader interpretation of the concept of Fitrah, it has various meanings like what has been interpreted and defined by many experts above. The meanings are: 1) "thuhr "(sacred), 2) Islam, 3) "Tawhid" (acknowledging the Oneness of Allah), 4) "Ikhlas" (pure), 5) the human's tendency to accept and practice righteousness, 6) "al-Gharizah" (instinct), 7) basic potential to serve Allah SWT, 8) the provisions on human's nature, both happiness and misery (Arifin, $2000: 7$ ).

The word is also applied to the newborn baby because he is not contaminated with something so that he is often referred to a state of Fitrah (sacred). Because of this sense, Fitrab is often associated with the purity so that the id al-Fitr is often interpreted by returning to the purity and zakat al-fitrah is too. This meaning is not always true. Fitrah is also used in the sense of the creation of the sky and the earth with a sense of balance as stated in the Qur'an.

Words that are usually used in the Koran to show that God enhances his creation to complete the creation is ja'ala which means "to make", which is placed in one verse after the word khalaqah and ansy'a. Embodiments and further improvements are given in humans (Achmadi, 2005 : 41).

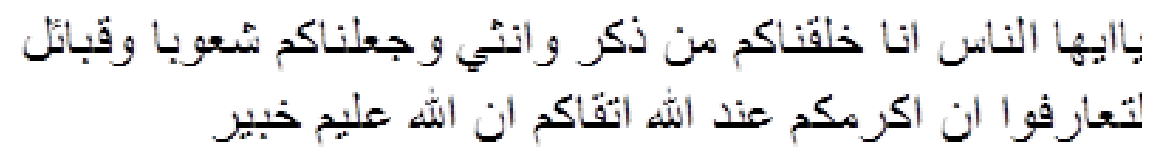

Translation: $\mathrm{O}$ mankind! We have created (khalaqna) you from a male and a female and made (ja'alna) you nations and tribes that you may know each other (Q.S. al Hujurat/ $49: 13)$.

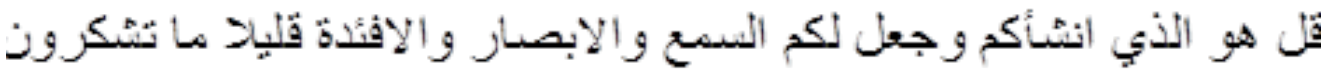

Translation:

Say: He created you (ansya'akum) and made (ja'ala) you hearing, vision and heart (Fuad), but very little you grateful (Q.S. al Mulk/ $67: 23$ ).

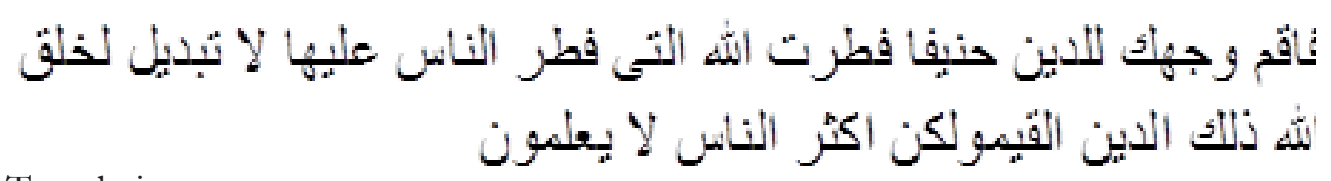

Translation:

So turn your face straight to the religion of Allah, remain on the Fitrah of Allah which has created (Fathara) human beings based on the Fitrah. No change in the Fitrah of Allah That is the right religion, but most men do not know (Q.S. ar Rum/ $30: 30$ ). 
The word "Fitrab", based on terminology, can be understood in a broad sense. As a basic understanding, as explained in surah al-Rum verse 30, it can be understood that the first thing created by God is the religion (Islam) as a guidance or reference, in which based on this reference human beings are created in the best condition. Due to a variety of negative factors that influence them, then the position of human being can be "shifted" from their Fitrah, for that guidance is always needed, warnings and guidance from Allah, delivered by His Messenger (Sipahutar \& Arifinsyah, 2003 : 18).

Simple definition based on its terminology, according to Arifin, is that Fitrah contains the potential in human's thinking ability where ratios or intelligence is the center of his development in understanding the religion of Allah peacefully in this world (Arifin, 2008 : 158). Quraish Shihab argues in his Tafsir al Misbah, that Fitrab is "creating original thing/without any preceding example". The view of Quraish Shihab, that Fitrah is an element, systems and working procedures created by Allah since the beginning of events to be innate is called by him with the original meaning of events, or inborn (Quraish Shihab, $2002: 53$ ).

Similar definition is also stated by Arifin that in the view of Islam, the basic ability/disposition is called as Fitrah (Arifin, $2000: 7$ ). Some people suggest that Fitrab is the faith about the Onenes of Allah SWT, implanted within every human being by Him. Therefore, men since birth have had an innate religion, i.e.: the religion of Tawhid (Baharuddin, 2004 : 148). The term of Fitrah can be viewed in two sides. In terms of language, Fitrah is an innate human nature. In terms of religion, Fitrah means religious belief, namely that men since birth has had Tawhid relgion, namely the Oneness of God.

Imam Nawawi defines Fitrah as a condition of uncertainty (unconfirmed state) that occur until an individual consciously express his faith. Meanwhile, according to Abu Haitam, Fitrah means that humans are born with goodness or putridity (prosperous or unprosperous) associated with the spirit. ${ }^{1}$ Then, based on this definition, it is implied that originally human beings created by God are given Fitrah (a balance). When this balance can be nurtured well, the individual will always be in goodness. Conversely, if this balance is not nurtured well, it will make the person fall to putridity. Fitrah is a word that is always used to indicate the holiness. Even in the abstract existence, it has always been associated with moral issues. This abstractness, although always used in certain aspects, mostly has the same sense, which is balance.

\section{Theory of Fitrah in Schools of Philosophy}

\section{Nativism}

Nativism comes from the word Natus (born); nativist (innate), which its teach-

1 His point of view is based on well-known Hadith, "Everyone is born in fitrah state. Then, his parents who will make him Jew, Christian, or Zoroastrian". In other description, Juhaya S, Praja states that Fitrah is innate since birth. 
ing views that human since birth has brought strength called a potential (Purwanto, 1994 : 16). This school of thought, opposite with leibnitzian tradition, emphasizes innate ability of children, so that environmental factors, including education, are less influential on the development of children in the learning process. In other words, nativism believes that everything is determined by innate factors so that the individual's development was solely made possible and determined by the base of a derivative, for example: if the a father is smart, then most likely his children are also smart.

Nativism views that the baby was already born with innate good and bad traits. Therefore, the terminal result of education is determined by the child's innate potential. According to this view, the success of education is determined by the students themselves. It is stressed that "the bad will be bad evil, and "the good will be good". Education which does not comply with the talent and disposition of the students would not be useful for the development of their own children in their learning. For nativism, the environment does not mean anything because the environment will not influence the child's development. Nativism views that if a child has a nasty disposition, he will be evil, otherwise if he has a good disposition, then he becomes a good person. Bad and good disposition cannot be changed from outside forces (Umar \& La SUla, 2000 : 196).

In his book, Educational Psychology, Muhibbin Shah mentioned that nativism is a pessimistic school of thought viewing everything with sunglasses. Why is that so? Because experts of this school of thought believes that human development is determined by disposition, while experiences and education do not affect anything. A child is born with his own disposition and will develop in accordance with his innate nature.

It is exemplified that there was a mother who gave birth to her son in the middle of the forest, but the mother died instantly. The baby was then raised by a wolf, taking care, feeding, and doing things for him. This could be construed as an education (environment) affecting the child. We know that wolf walks by using its four legs. However, later the wolf felt strange when the child can run by using only two legs though he gave an example of him with four legs. Based on this example, according to Nativisms, education is no use at all. Thus, according to them, children do not need to be educated, as being a good or bad has been determined by their innate potential since birth (Muhibbinsyah, $1997: 42$ ).

Nativistic philosophy says that there are several factors that influence human development. Firstly, it is genetic factor. It is genetic factors from both parents which lead to talent in their children. if a parent, for example, is a singer, his children will have innate talent as a singer. The second factor is child's ability. It is a factor that makes a child know that there is potential in him. This factor is more real because children can develop the potential that exists within him. An example is their extracurricular activities in schools that encourage each child to develop the potential within themselves according to their talents and interests. 
The third factor is the growth of the child. It is a factor that encourages children to know their talents and interests in any natural growth and development so that if the growth of the child is normal, he will be energetic, active, and responsive to his capabilities. Conversely, if the child's growth is not normal, the child cannot recognize his talents and capabilities (http://nadhirin.blogspot.com/2010/03/teori-nativisme.html).

Thus, it can be understood that the navitisms acknowledge innate potentials that exist in human beings or Fitrah in Islam. According to Navitisms, a person's success in the educational process is dominated by internal factors in students themselves. The terminal outcome of education is determined by innate talent possessed by a child when he was born. Education which is not in accordance with is not required in the learning process.

\section{Naturalism}

Many ideas of the philosophers back then resulted in many schools of thought in philosophy. All of schools of thought are based on deep thinking motivated by many different factors.

Among schools of thought, one of which is naturalism. The philosophy of naturalism appeared as a reaction to educational school of thought, namely Aristotalian-Thomistic. Naturalism emerged in the 17th century and had developed in the 18th century. Naturalism developed rapidly in the field of science. It viewed that "Learned heavily on the knowledge Reported by man's sense" (George R., 1982).

Naturalism was derived from the word "nature." Sometimes definition of "nature" is only in the sense of the material things alone. Things other than the physical things are automatically "supernatural". In fact, nature is composed of a material and spiritual realms, each is on its legal. Age of Enlightenment, for example, viewed that nature was not as the existence of physical objects but as the origin and foundation of the truth. It did not contrast material with the spiritual. The term includes not only the physical nature but also intellectual and moral nature (http://kuwatpamuji.blogspot.com/aliran-filsafat-pendidikan/html).

One of the most amazing characteristics of the universe is order. The human mind had seen this order since back then. The fact that the rising and setting sun, the circulation of the planets and the arrangement of the stars moving regularly from night to night had been noticed by human is a simple example. Science itself only became possible because of the regularity which is then communicated through the laws of mathematics. The task of science can generally be said to be examining, reviewing, and connecting all the regularities observed. Science aims to answer the question of how and why. Specifically for cosmology, however, the question 'why' at some point experience tremendous difficulties.

Naturalism is a theory that received the "nature" as the whole of reality. The 
term "nature" has been used in philosophy with a variety of meanings, ranging from the physical world that can be seen by man, to the total system of the phenomenon of space and time. Nature is a world that is revealed to us by natural science. The term naturalism is the opposite of the term supernaturalism containing dualistic view of nature with the powers (form) which are above or beyond nature (Harold, 1984).

School of philosophy of naturalism is supported by three major schools, namely realism, empiricism and rationalism. Basically, all adherents of naturalism is an adherent of realism, but not all believers of realism are adherents of naturalism. Imam Barnadib mentions that realism is the "son" of naturalism. Therefore, a lot of ideas of thought in realism are in line with naturalism, one of which is that aesthetic and ethical values can be obtained from nature, because these two things exist in nature.

The main and first dimension of naturalism in the field of education is the importance of education in accordance with the development of nature. Man was created and placed above all creatures because of his ability to think. Learners must be prepared to and for God. For that reason, education related to this view is education about God, manners and intellect. Education is not only to make someone want to learn, but also to make someone wiser and more prudent (Bertens, 1988).

The recognition of this school about basic potential possessed by human beings can be seen from the statement of well-known naturalist, namely JJ Rosseau. Rosseau believes that everyone since birth has had the basics of good moral. Rousseau uses the term "noble savage" to describe the moral aspects, namely things about good and bad, right or wrong, as the potential in children since birth. The views of Rousseau became the starting point of the view emphasizing innat potential as an important factor of the content of one's psyche and personality. Characteristics shown by someone is intrinsic, and therefore, the view of Rousseau is classified into view of Nativism (Alex, 2003 : 148).

Naturalism in educational philosophy teaches that the most natural teacher of a child is parents (http://akhmadsudrajat.wordpress.com/2008/11/08/aliran-aliran-filsafat-pendidikan/). Therefore, education for naturalists should be begun long before the educational process implemented. School is the main base in the naturalism because learning is something that is natural. Therefore, the fact that it requires teaching also something that is natural too. Naturalism views that teachers do not teach subjects, but students.

There are five well-known educational goals of naturalism introduced by Herbert Spencer through the famous essays entitled "What is the Most Valuable Science?" The five goals are: (1) self-maintenance; (2) securing the necessities of life; (3) increasing the students; (4) maintaining social and political relationships; and (5) enjoying free time.

Spencer also explains the seven principles of the educational process in 
naturalism. They are: (1) education should adapt to nature; (2) the educational process should be fun for the students; (3) education should be based on the spontaneity of the child's activity; (4) increase the knowledge is an important part in education; (5) education is meant to help the physical and the brain development at the same time; (6) the teaching practice is the art of delay; (7) instruction in the education uses inductive method; (The penalties are imposed as a consequence of nature due to make mistakes. If punishment is given, it should be done sympathetically (Wakhudin \& Trisnahada, $1997: 5$ ).

\section{The Theory of Fitrah in Islam}

Differ from those theories of Fitrah as explained above, based on the understanding of the above and referring to Al-Quran and Al-Hadith, Fitrah of human according to the teachings of Islam can be described as follows:

1. The Prophet Muhammad SAW mentioned that Fitrah is potential carried by human being since he was born on the Earth and continue to develop in accordance with his interaction with the environment.

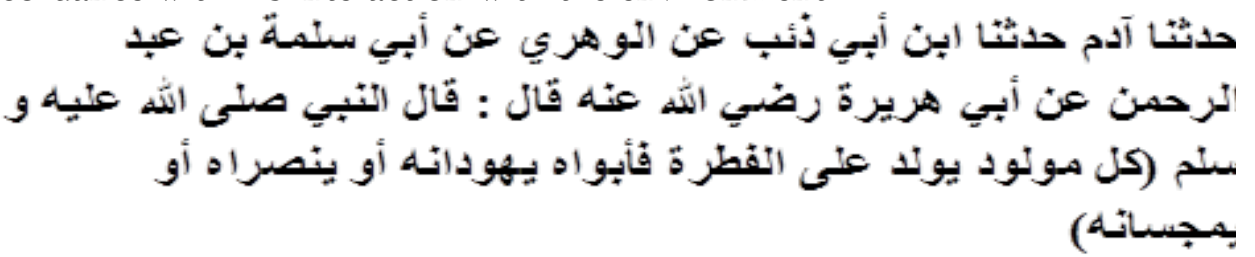

“Told to us, Adam, told to us, Ibnu Abi Dzi 'bi from al-Wahri from Abu Salamah from Abdur Rahman from Abu Hurairah ra, The Prophet Muhammad SAW says: "each baby is born in the state of Fitrah (holy), his prents make him Tiap bayi dilahirkan dalam keadaan fitrah (suci), orang tuanyalah yang membuat dia Jew, Christian, Zoroastrian." (Al Bukhari, $1992: 465)$

2. Human being is psycho-physical creature that has a spirit and body. Of the various verses of the $\mathrm{Al}$-Qur'an, it can be seen that the identity of man is a psycho-physical creature, whose existence consists of elements of spirit (spirit) and physical (body). The combination of this is embodied into a human. The verse that supports this statement is:

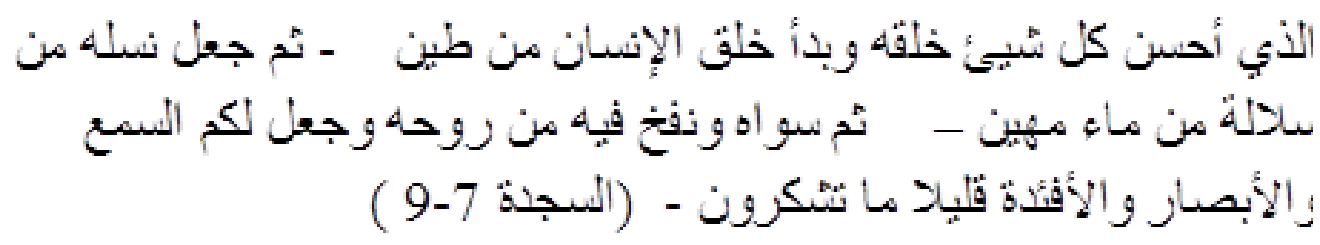

This verse confirms that the first man was created from the ground (thin). Then, the next generation is from element of sulalat min ma mabin, semen. It shows that 
humans have a physical element. In addition, God breathed spirit into the physical element. After the physical form is filled with the spirit, forming a distinctive type of creature is formed, the man. The existence of these two elements, the physical and spirit element, necessitates the presence of the attributes of both elements besides the attributes from the combination of both of them.

\section{The Nature of Corporeity (al-fithrat al-jismiab)}

The human body is a material that has physical properties. It is made up of four elements that make up the material realm, namely soil, water, air, and fire. Muslim philosophers, such as Ikhwan al-Shafa' suggests that the balance of the composition of these four elements influence human traits (Ikhwan, 1957 : 259).

The human body consists of parts and members, each of which has its duties and functions independently. The arrangement of each part and member is perfectly proportioned so that everything can give optimal contribution for human physical perfection and functionalization of each part. This fact is illustrated in AlQuran Surah Al-Tin verse 4, which is: Surely we created man in the best form (fi ahsani Taqwim).

The shape and structure of human's physical parts are designed in such a way so that a man can perform various activities assigned to him. Only when a man is created (born), the condition of each part is still in a weak state and potential in nature. It can be seen from the Al-Quran Surah al-Rum Verse 54 and Surah alNisa`Verse 38 (Q.S. Ar-Rum : 54).

\section{The Nature of Spirit (al-fithrat al-rubiyyat)}

The spirit is the essence of human nature. It is this element which has the task as a vicegerent of God on earth. This element is also responsible for all human behavior and actions. Only, unfortunately, this element has become a mysterious part. $^{2}$

In the Qur'an it is stated that the human's spirit comes from God's spirit (min ruhih). ${ }^{3}$ In addition, the scholars also conclude that this element also has an agreement with The Creator before it is merged with the body. ${ }^{4}$ Based on all these, of course, it is impossible that man is created in a wrong path and sinful as understood by some people.

That's why most experts believe that human beings are created in a state of Tawhid, Islam, and sacred. However, this argument is only true as long as mankind is viewed only in terms of his original spirit. Muslim scholars agree that the creature called man does not only consist of the spirit alone, but also has physical element. The condition of human's spirit when a child is born, after merged with

2 Al-Quran emphasizes that spirit is God's business. See QS.: al-Isra 'verse 85

3 See QS.: Al-Sajadah, verse 9, al-Hijr, verse29, and Shad, verse 72

4 This view is based on interpretation of Al-Qur'an Surah Al-A'raf, verse 172 
the body, has no awareness of the mandate and the promises. The unification of the spirit with the material body makes the spirit prevented to to know and realize his promise to God. The Quran states:

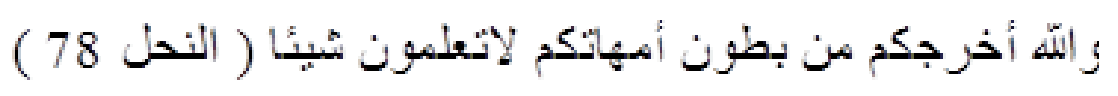

4. The Nature of Pycho-physical (al-fithrat al-nafsaniyyat)

What is meant by nafs (self) is an essence that is formed after the unification of physical and mental elements. Nafs is not the same as the spirit which has become the secret of life and also not the same as the body which can be observed (Syati', 1999 : 155).

Thus, the fitrab nafsaniah is the state and the nature of the unification between spirit and physical element. It is not the state of spirit like described above. It is a state and nature of spirit merged with the body. It is also not the state of physical element only, but a state where the physical element has been merged with the spirit. $^{5}$

The descriptions about Fitrah Nafsaniah in Al-Qur'an are as follows:

a. Weak. Human beings are born in a weakened state, both physically

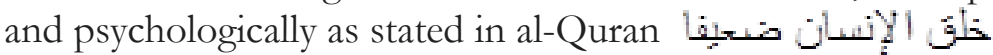

b. Has the potential to perform a variety of physical work. Although humans are born in a weakened state, no power at all ${ }^{6}$, it can grow to be strong to do all kinds of physical action after going through the process of growth and development. The demand that human beings create prosperity on earth and do not do any damage shows that they can perform positive or negative actions.

c. Stupid in the sense of having no knowledge about anything. The Quran

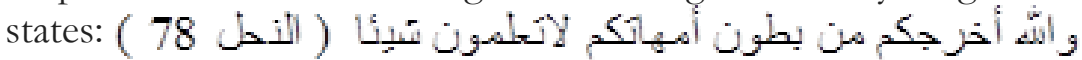

d. Has the potential to be knowledgeable. Along with the above statement, humans are created in a potentially knowledgeable state. There are three tools that God has given for this purpose, namely: auditory (al-sam ), sight (al-bashar), and heart (al-af idat).

e. Has the freedom to act and behave. Humans are born with the potential that allows them to determine choices of all the actions which they will do. They are given the freedom to choose whether they will be believers or not. Note the following verse:

5 The fact that man is a combination of physical and spiritual element determines fitrab nafsaniab in every human being. Various possible combination of these two elements will embody the uniqueness of the human. He will be the main basis for the formation of individual differences in each human being. Abdullah states that the process of unification of the spirit within the body is similar to the chemical process(reaction) of two chemical substances.

6 Compared to animals, humans are born in a weaker state. Within a few minutes after birth, the animals can walk or run, while men don't. Humans are born in a state of "premature". In order to be more powerful like animals, people take about two years in his mother's womb. 


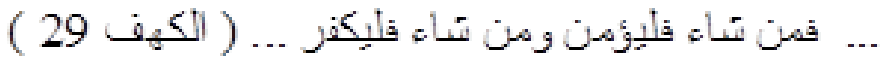

f. Neutral in terms of the potential to be good and evil as goodness or badness has been given in human beings. In relation to this, Al-Qur'an mentions:

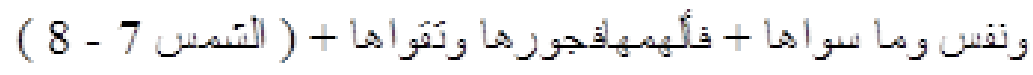

g. Allah has created men to be His vicegerent. This shows that humans must have the potential to be good. However, it should be remembered that behind it, they also have the potential to become evil. The physical element which is always in a state of al-Kawn wa al-facade has the potential to dominate the pure element of the spirit. When the physical element is dominant, undoubtedly the evil will become real. Ideally, spiritual element must be dominant over the physical elements.

Along with this information, the meaning of Fitrah as potential, especially good potential, is not quite right. Fitrah means to be a potential, namely the potential to be good and not good.

\section{Breaking the Path to the Fitrah-Based Education}

The concept of Fitrab is basically believing that the direction of movement of human's life (students) is largely divided into two, namely taqwa and fujur. Students are essentially created in a state of having a positive potential and they can move toward piety. If a man walk straight between Fitrah and Allah, he will be taqwa (healthy, safe). If he is not in harmony between Fitrah and Allah, he will go to the misguided path (fujur). By his Fitrah, man is created with love, having love, but he can shift toward aggression. However, the implications referred to in this research define the concept of Fitrah according to the current reality, that the values of the actualization of the function of Fitrah are in line with the goal of education, which is in epistemology of education, realizing students who have the potential of Muslim personality which is oriented towards the actualization of the concept of human's Fitrah.

Jakfar Siddik states that the core of humanity is the fitrah (religion) itself. Fitrah makes humans (students) naturally possess a good soul and sacred desire and take side with goodness and truth of Allah SWT (Siddik, 2004 : 147). The writer thinks that if a process of development of learners in the educational environment as way to develop the good potential of learners (the concept of fitrah) can be met, the personality needs of learners will be better.

The potential of the learner, as a child who has the mandate of Allah and a inheritor on this earth, was born with the value of tawhid. According to Nurcholish Madjid, with the agreement between creatures (human beings) and Allah SWT, it can be said that men (students) are bound by the agreement (religious meaning). 
Similarly, religion is actually indeed an agreement, which in Arabic it is called mitsaq or 'abdun, an agreement with Allah SW'T. The whole life is the realization or implementation of the agreement between men and Allah SWT. The point is to worship, meaning that men enslave themselves to Allah SWT because Allah has been acknowledge as Rabb. The implication of worshipping Allah is that students who are hungry for the needs of their development of fitrah personality are required to live their life in a guided path (Madjid, $2000: 224$ ).

Achyar Cholili in his book mentions that the concept of Tawhid-Based Education has two substances of interest: (1) to stimulate and encourage the growth of students' life skills which are rooted from students' fitrah. Life skills which have two main dimensions, namely social and personal skills, bring to the self-awareness. This awareness of life makes students understand that their basic potential has to be developed optimally; and (2) Tawhid-based education is to return back to the Oneness so that the universe becomes a means of remembrance and learning for the students (Chalil \& Latuconsina, 2008 : 2-3).

Basically, the concept of fitrah when implemented in education, is not just about "tranfers of knowledge" or "tranfers of training", but much of it is a system that is laid on a foundation of faith and piety; a system that is directly related to God, and this is a potential of tawhid which is part of the concept of fitrab. The main point is that the significance of the concept of fitrab in relation to the area of education is to create an activity that leads to the development of a person which is in line with Islamic values. The concept of fitrab which is a basic human potential can be actualized when the the condition of the environment and the process of education can shape the values of Islamic personality. Globally, the potentials direct students to be a religious individualist and socialist. In other words, the potentials of fitrah manifested in an individual are the values of objectivity of transcedental moral humanism, especially on the issue of the development of personality towards Muslim personality where it is part of the process of internalizing the values of fitrah into the education that is based on Islam.

In the view of the concept of fitrah in Islam, human beings have a power to grow and are also ready to be developed. However, it does not mean that human beings are treated passively. They have an ability to make judgment, accept, decline, or determine other alternatives which are more rellevant with his choice as the embodiment of their free will and desire.

Therefore, the significance of Islamic education within the framework of the concept of fitrah can be described as a system that brings people toward happiness in this world and hereafter through both science and worship, because the ultimate goal of Islamic education itself is the attainment of happiness of living in the world and prosperity in afterlife. Therefore, the main focus is to concern about the values of Islam about men: their nature, their mission and purpose of living in the world and the hereafter, and rights and obligations as individuals and members of society. Hence, once someone knows about the nature of life, he is 
not only to become inspiration to other human beings, but also to be able to transfer the noble values that he has developed: a peron who loves to live in peaceful, safe and prosperous way because the real fitrah of human being is to live by loving each other.

\section{Conclusion}

The concept of fitrab when associated with Islamic education is actually a very religious approach which gives more emphasis on faith, because every human being is born with potential which is the potential of the belief in Allah or tawhid. The meaning of fitrah in the Qur'an is the image that actually human being is created by Allah SWT with religious instinct, which is tawbid religion. Hence, those who do not believe in tawhid religion has been astray from their fitrah.

After understanding the concept of fitrab in a broad sense, the objectives are the movement of Islamization of education based on the teaching of Islamic educational system. With the paradigm of humanism theocentric based on the concept of fitrah, it is expected to not only be able to become a measuring tool of productivity development of students, but also be able to make the operational implementation systematic, logical and objective about Islamic teachings, not the opposite way in which students' productivity is based on the Western philosophical about humanity theories, which do not necessarily provide a description of religious values needs of the students themselves.

It is necessary to be affirmed that the needs of the religious values of students which are in accordance with objectives of Islamic education should be based on theory of the concept of fitrah as all efforts in improving Islamic education system must maintain and develop students' fitrah in order to make human resources become a whole man (insan kamil) in line with the Islamic norms.

Along with the objectives of fitrah concept in the Islamic education system, the concept of fitrah of the students can be formed as a true and perfect muslim. Pious man who has abilities of actualization of his relationship with Allah, other men, and nature postively and constructively is called transcedental humanism theocentric. With the Islamic education based on the concept of fitrah, it is expected that students deserve a position of eligible servant of Allah SWT as described in Al-Qur'an.

Islam as a religion of fitrab does not only fit the instincts of human religiosity, but also support the growth and development of his fitrah so that it will lead to personal wholeness and perfection. On the other hand, Islam as a way of life which is based on the values of God, both described in the Qur'an and al-Hadith is believed to contain the absolute truth which is transcendental, universal and eternal (everlasting) so that it is believed by its adherents that Islam will always fit in human fitrah, that it meets human's need anytime and anywhere (likulli zamanin wa makanin). 


\section{References}

Abul A'la Al-Maududi, Towards Understanding Islam, Islamic Publication LTD, Lahore-Dacca. 1966

Achmadi, Ideologi Pendidikan Islam, Paradigma Humanisme-Teosentris (Yogjakarta: Pustaka Pelajar, 2005)

Achyar Chalil dan Hudaya Latuconsina, Pendidikan Berbasis Fitrah (Balai Pustaka, Jakarta: 2008)

Aisyah Bintu Syati ', Manusia Dalam Perspektif al-Quran, Terj. Ali Zawawi, (Jakarta: Penerbit Pustaka Firdaus, 1999)

Al-Bukhari, Abu Abdullah Muhammad bin 'Ismail. 1992. Shabih al-Bukbari (Juz 1. Cet. 1. Beirut: Darul Kutub al-'Ilmiyah)

Arifin, Filsafat Pendidikan Islam, cet. VI (Jakarta: Bumi Aksara, 2000) , Ilmu Pendidikan Islam Suatu Tinjauan Teoristis dan Praktis Berdasarkan Pendekatan Interdisipliner, cet V (Jakarta: Bumi Aksara, 2000)

A.W. Munawwir, Kamus al Munawwir; Arab-Indonesia, cet. XIV (Surabaya: Pustaka Progressif, 1997)

Baharuddin, Paradigma Psikologi Islami Studi Tentang Elemen Psikologi dari AlQur'an (Yogyakarta: Pustaka Pelajar, 2004)

Bertens. K. Filsuf-Filsuf Besar Tentang Manusia. Kanisius. 1988 dalam http://astaqauliyah.com/2007/01/20/filsafat-naturalisme/

Dja'far Siddik, "Menelusuri Konsep Proses Pembelajaran dalam Sistem Pendidikan Islam" dalam Hasan Asari, Amroeni Drajat, (ed), Antologi Kajian Islam (Bandung: Citapustaka Media, 2004)

George R. Knight, 1982, Issues and Alternatives in Educational Philosophy, Michigan : Andrew University Press dalam http://eduartikel.com/aliran-filsafat-pendidikan

Ikhwan al-Shafa ', Rasail Ikhwan al-Shafa’, (Beirut: Dar Shadir, 1957)

Luis Ma'luf, al Munjid fi al lughah wa al a'lam (Bairut: Dar el Mashreq, 2000), p. 588. lihat Atabik Ali dan Ahmad Zuhdi Muhdhor, Kamus Kontemporer Arab-Indonesia, cet. V (Yokjakarta: Multi Karya Grafika, 1996), p. 1399

LPKUB, Ensiklopedi Praktis Kerukunan Hidup Umat Beragama, P.Sipahutar dan Arifinsyah (Ed.) 2nd edition (Bandung: Citapustaka Media), 2003

M. Ngalim Purwanto, Ilmu Pendidikan Teoritis dan Praktis (Bandung: remaja Rosdakarya, 1994)

Muhibbinsyah 1997. Psikologi Pendidikan dengan Pendekatan Baru. (Bandung: Remaja Rosdakarya, 1997) 
Nurcholish Madjid, "Pesan-Pesan Takwa Nurcholish Madjid", Editor Asrori S. Karni, (Jakarta: Paramadina,2000)

Quraish Shihab, Tafsir Al-Mishbah; Pesan, Kesan dan Keserasian Al-Qur'an, Vol 11 (Jakarta: Lentera Hati,2002)

Umar Tirtarahardja dan La Sula, Pengantar Pendidikan (Cet.1; Jakarta; Rineka Cipta,2000)

Subor, Alex. Psikologi Umum. (Bandung: Pustaka Setia, 2003)

Wakhudin dan Trisnahada. Filsafat Naturalisme. (Makalah) Bandung: PPS-UPI Bandung, 1997 